\title{
Risiko for atrieflimmer hos friske middelaldrende menn
}

\author{
Høyt normalblodtrykk, høy kroppsmasseindeks samt lav arbeidspuls \\ hos menn i god fysisk form ser ut til å være en indikasjon på senere \\ atrieflimmer.
}

Forekomsten av atrieflimmer er sterkt økende i befolkningen. For effektiv og målrettet forebygging er det nødvendig å kjenne til forhold som kan gi økt risiko for å utvikle atrieflimmer. I mitt doktorarbeid har jeg og mine medforfattere sett på slike faktorer.

Vi har analysert data fra 2014 friske norske menn $i$ alderen 40-60 år som ble grundig undersøkt i 1972-75 og fulgt til 2007. Opplysninger om sykdom og død er hentet fra sykehusjournaler og Dødsårsaksregisteret. Data er analysert ved klassiske epidemiologiske statistiske metoder.

I løpet av 35 års oppfølging utviklet 270 menn (13\%) atrieflimmer. Gjennomsnittlig debutalder var 70 år. Resultatene indikerte at ikke bare høyt blodtrykk, noe som er velkjent, men også blodtrykksverdier i øvre normalområde ser ut til å være en indikasjon på senere atrieflimmer. I tillegg fant vi at høy kroppsmasseindeks ga økt risiko for atrieflimmer, men signifikant kun hos menn med fysisk kapasitet lavere enn gjennomsnittet, bedømt ved maksimal sykkelbelastningstest.

Menn i god fysisk form som hadde lav arbeidspuls ved moderat belastning på ergometersykkel, hadde også høy langtidsrisiko for atrieflimmer. Spesielt var risikoen økt dersom de samtidig hadde forhøyet blodtrykk.

Våre langtidsresultater gir ny kunnskap om sammenhengen mellom lett målbare kliniske variabler og fremtidig risiko for atrieflimmer hos i utgangspunktet friske menn.

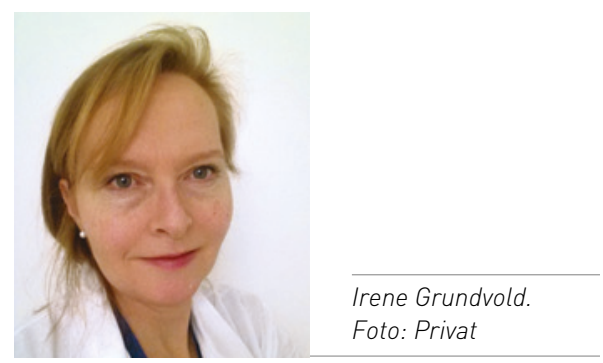

Disputas

Irene Grundvold disputerte for ph.d.-graden ved Universitetet i Oslo 26.5. 2014. Tittelen på avhandlingen er Long-term predictors of atrial fibrillation in healthy middle-aged men.

\section{Selvregulering av hjernefunksjonen ved $A D / H D$ hos barn og ungdom}

\section{Selvregulering av hjernefunksjonen med «neurofeedback» viste lovende effekter $\mathrm{i}$ behandling av barn og ungdommer med AD/HD.}

AD/HD er en nevropsykiatrisk, multifaktoriell utviklingsforstyrrelse preget av mangel på selvregulering. Prevalensen varierer fra $2 \%$ til $7 \%$ på verdensbasis. Tidlig symptomdebut er karakteristisk, og vanskene kan vare ved inn i voksen alder og påvirke utdanning og sosiale og emosjonelle ferdigheter. $\mathrm{AD} / \mathrm{HD}$ kan behandles medikamentelt, men ikke alle har god effekt av behandlingen.

I arbeidet med avhandlingen gjennomførte vi er en randomisert, kontrollert studie, hittil den største i Norge, med 130 barn og ungdommer henvist til og diagnostisert med $\mathrm{AD} / \mathrm{HD}$ ved BUP, Haugesund. Hovedmålet var å undersøke effekten av «neurofeedback» $\mathrm{i}$ behandlingen, slik det ble rapportert fra foreldre, lærere og barnet/ungdommen selv.

«Neurofeedback» er trening i selvregulering av hjernefunksjonen ved å kontrollere egen atferd og symptomer på en hensikts- messig måte - ved hjelp av «operant betinging og positiv forsterkning».

Resultatene indikerer at bare halvparten av barn/unge henvist for $\mathrm{AD} / \mathrm{HD}$-symptomer til BUP møtte kriteriene for tilstanden. Dette tyder på at det er behov for å bedre kunnskapen om AD/HD i primærhelsetjenesten.

«Neurofeedback» viste lovende effekt $\mathrm{i}$ behandling av $\mathrm{AD} / \mathrm{HD}$ sammenliknet med medisiner ut fra det som ble rapportert fra foreldre, lærere og barn/unge kort tid etter behandlingen. Dette kan åpne for muligheten til å bruke metoden som alternativ behandling for dem som ikke responderer på medisiner eller får ugunstige bivirkninger av medisinbruk. Langtidsoppfølging er nødvendig for å evaluere effekten på sikt.

Nezla Sehovic Duric nezlad@gmail.com

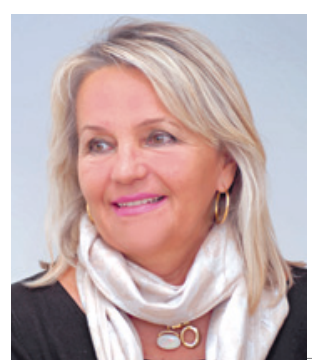

Nezla Sehovic Duric. Foto: Erik Dankel

Disputas

Nezla Sehovic Duric disputerte for ph.d.-graden ved Universitet i Bergen 4.9. 2014. Tittelen på avhandlingen er Children and adolescents with Attention Deficit Hyperactivity Disorder. Characteristics and treatment with neurofeedback. 